\title{
A Case Report of Pseudoxanthoma Elasticum with Rare Sequence Variants in Genes Related to Inherited Retinal Diseases
}

\author{
Francesco Demetrio Lofaro ${ }^{1}$, Dario Pasquale Mucciolo ${ }^{2} \mathbb{D}$, Vittoria Murro ${ }^{2}$, Laura Pavese ${ }^{2}$, Daniela Quaglino ${ }^{1} \mathbb{D}$ \\ and Federica Boraldi $1, *$ (D)
}

Citation: Lofaro, F.D.; Mucciolo, D.P.; Murro, V.; Pavese, L.; Quaglino, D.; Boraldi, F. A Case Report of

Pseudoxanthoma Elasticum with Rare Sequence Variants in Genes Related to Inherited Retinal Diseases.

Diagnostics 2021, 11, 1800. https:// doi.org/10.3390/diagnostics11101800

Academic Editor: Ramin Khoramnia

Received: 26 August 2021

Accepted: 27 September 2021

Published: 29 September 2021

Publisher's Note: MDPI stays neutral with regard to jurisdictional claims in published maps and institutional affiliations.

Copyright: (c) 2021 by the authors. Licensee MDPI, Basel, Switzerland. This article is an open access article distributed under the terms and conditions of the Creative Commons Attribution (CC BY) license (https:// creativecommons.org/licenses/by/ $4.0 /)$.
1 Department of Life Science, University of Modena and Reggio Emilia, 41125 Modena, Italy; francescodemetrio.lofaro@unimore.it (F.D.L.); daniela.quaglino@unimore.it (D.Q.)

2 Department of Neuroscience, Psychology, Drug Research and Child Health, University of Florence, Eye Clinic, 50139 Florence, Italy; dario.mucciolo@gmail.com (D.P.M.); vittoria.murro@unifi.it (V.M.); laurapavese4@gmail.com (L.P.)

* Correspondence: federica.boraldi@unimore.it

\begin{abstract}
A case of a patient with an early and severe visual impairment is described. Due to the occurrence of skin papules a suspect of pseudoxanthoma elasticum (PXE) was posed. PXE is a rare autosomal recessive disease clinically characterized by skin, cardiovascular and ocular manifestations, these last being those that most severely affect patients' quality of life. A whole exome sequencing approach focusing on 340 genes related to the calcification process and/or to inherited retinal diseases (IRDs) was performed. Rare monoallelic sequence variants in ABCA4, ABCC6, IMPG1, POC1B and $R A X 2$ were found. The presence of calcified elastic fibers was assessed by ultrastructural analysis on a skin biopsy. Diagnosis of PXE was based on clinical, biomolecular and morphological results, although the additional involvement of several IRD genes is important to explain the unexpectedly severe ophthalmological phenotype of the patient also in prognostic and therapeutic perspectives. Data indicate that genetic screening using a wide-spectrum analysis approach is essential to assist ophthalmologists in improving patient counseling.
\end{abstract}

Keywords: pattern dystrophy; retinal atrophy; ABCC6; ABCA4; IMPG1

\section{Introduction}

Pseudoxanthoma elasticum (PXE; OMIM\#264800) is a multisystem ectopic mineralization disorder characterized by fragmentation and calcification of elastic fibers [1,2]. Although several organs are involved, clinical manifestations occur mainly in the skin [3], eyes [4] and the vascular system [5]. Skin is characterized by papules in the flexural body areas which may be associated with skin laxity. The ophthalmological manifestations consist, initially, of peau d'orange, angioid streaks and comet lesions to which choroidal neovascularization (CNV) and possibly also dystrophy and atrophy are added over time, causing severe visual impairment in aging patients [6]. Mineralization of elastic fibers of blood vessels may lead to the onset of peripheral artery disease, claudicatio intermittens and stroke whose severity is highly variable $[5,7]$.

Inheritance of PXE is on an autosomal recessive basis and is mainly due to pathogenic variants in the ABCC6 gene [8], although in the last few years, the presence of pathogenic variants in calcification-related genes (e.g., vitamin K-dependent gamma-carboxylase (GGCX) or ectonucleotide pyrophosphatase/phosphodiesterase family member 1 (ENPP1)) has also been demonstrated [9-11]. Recently, the involvement of modifier genes has also been proposed [12]. For instance, pathogenic variants in $A B C A 4$ and in USH $2 A$ genes (i.e., genes responsible for inherited retinal diseases (IRDs)) were described in PXE patients $[13,14]$ and these findings are of particular interest as IRDs are a group of 
genotypically and phenotypically heterogeneous diseases that are characterized by ocular manifestations similar to those observed in PXE.

We describe an interesting case report trying to associate genetic data (i.e., rare sequence variants in calcifying and IRD genes) and ocular findings obtained with color fundus photograph (CFP) and optical coherence tomography (OCT), two important fundus imaging examination techniques used to study retinal abnormalities.

\section{Case Report}

A 46-year-old male underwent dermatological and ophthalmologic examinations (i.e., visual acuity, color fundus photographs, optical coherence tomography [OCT (Cirrus Spectral Domain OCT; Carl Zeiss Meditec Inc., Dublin, CA, USA), fundus autofluorescence). Routinary laboratory tests including assay for magnesium, phosphorus, iron, zinc, copper, alkaline phosphatase, folic acid, vitamin $\mathrm{B}_{12}$, homocysteine, $\mathrm{C}$-reactive protein, thyroid function and blood clotting factors were within reference range.

The patient was characterized by skin papules (Figure 1A) and by CNV that has been treated using photodynamic therapy ( 2 treatment sessions in the right eye) and intravitreal anti-vascular endothelial growth factor drugs (17 injections in the right eye and 1 injection in the left eye). Visual acuity was 6/10 in the right eye and 1/20 in the left eye. Fundus examination revealed angioid streaks and peau d'orange in addition to the presence of peripheral comet lesions and macular atrophy at the posterior pole (more severe in the left eye) with a juxtafoveal pigmented scar in the right eye and fibrotic tissue at the interpapillomacular region in the left eye. Moreover, pattern dystrophylike changes were evident at the posterior pole. OCT scan (HD Line Raster acquisition protocol) showed subretinal fluid with the ellipsoid zone abnormalities at the fovea with juxtafoveal hyperreflective alteration corresponding to the fundus scar in the right eye. At the interpapillomacular region, the atrophy of the outer retinal layer and retinal pigment epithelium (RPE) was evident (hypertransmission phenomenon). In the left eye, OCT scan showed widespread RPE atrophy with atrophy of the outer retinal layers (Figure $1 \mathrm{C}-\mathrm{F}$ ).
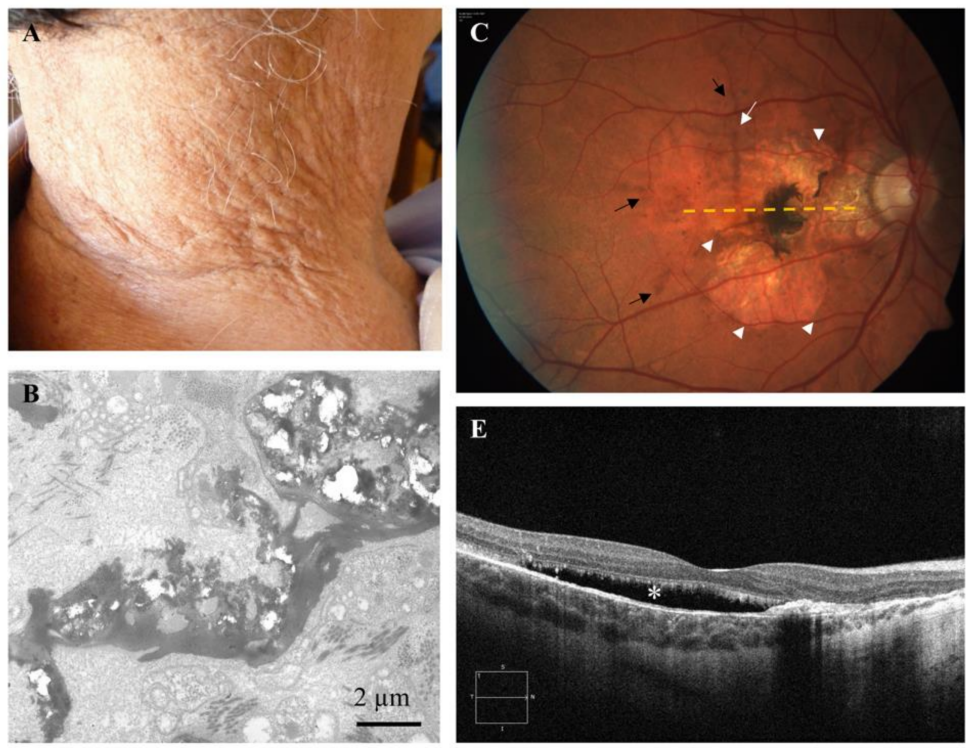
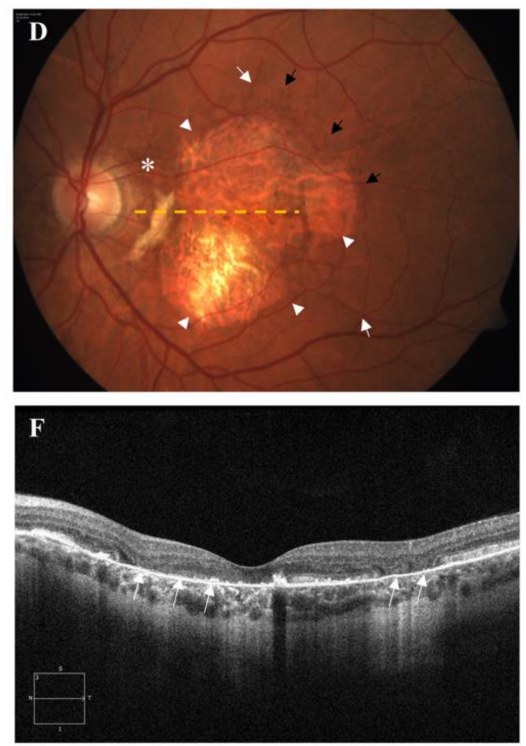

Figure 1. (A) Skin plaques in the neck area. (B) Mineral precipitates deforming, and cracking dermal elastic fibers are observed by transmission electron microscopy ultrastructural analysis. (C,D) Color fundus photographs of the posterior pole of the right and left eye show angioid streaks (white arrows), and macular atrophy (arrowheads) with a juxtafoveal pigmented scar in the right eye (C) and fibrotic tissue at the interpapillomacular region in the left eye (D) (asterisk). Pattern dystrophy-like changes (pigment deposition) were evident at the posterior pole (black arrows); orange dashed lines show OCT scan position. (E,F) Optical coherence tomography (OCT) examinations show subretinal fluid (asterisk) at the fovea in the right eye (E) and widespread RPE atrophy with atrophy of the outer retinal layers (arrows) in the left eye (F). 
A whole exome sequencing analysis was performed as already described [15], focusing on 340 genes known to be associated with the calcification process [11] and/or to be responsible for IRDs (RetNet, https:/ /sph.uth.edu/retnet/; accessed on 24 May 2021).

A search of the literature or a bioinformatic analysis using the VarSome platform [16] was performed to exclude that detected rare sequence variants were benign or likely benign.

The patient was therefore characterized by monoallelic rare sequence variants on $A B C A 4, A B C C 6$, IMPG, POC1B and RAX2 genes (Table 1).

Table 1. List of rare sequence variants in IRD genes found in patient in heterozygous state.

\begin{tabular}{cccccccccccc}
\hline Chr & $\begin{array}{c}\text { Gene } \\
\text { Symbol }\end{array}$ & $\begin{array}{c}\text { Exonic } \\
\text { Alteration }\end{array}$ & Exon & $\begin{array}{c}\text { Gene } \\
\text { Variant }\end{array}$ & $\begin{array}{c}\text { Amino Acid } \\
\text { Variant }\end{array}$ & ExAC & GnomAD & 1000G & dbSNP & Reference \\
\hline 1 & ABCA4 & ns & 48 & c.6647C $>$ T & p.Ala2216Val & $/$ & $/$ & $/$ & $/$ & [17] \\
\hline 16 & ABCC6 & ns & 26 & c.3707T>C & p.Met1236Thr & $/$ & $/$ & $/$ & $/$ & This study \\
\hline 6 & IMPG1 & ns & 14 & c.1945C $>$ T & p.Leu649Phe & 0.004802 & 0.00695 & 0.0014 & rs118155926 & {$[18]$} \\
\hline 12 & POC1B & ns & 3 & c.266T>C & p.Met89Thr & 0.000091 & 0.000032 & $/$ & rs780961965 This study \\
\hline 19 & RAX2 & ns & 2 & c.87G $>$ T & p.Arg29Ser & 0.000009 & $/$ & $/$ & rs778633054 This study \\
\hline
\end{tabular}

$\mathrm{Chr}=$ chromosome; $\mathrm{ns}=$ nonsynonymous; ExAC = Exome Aggregation Consortium; GnomAD = Genome Aggregation Database; 1000G = 1000 Genomes; / = no data available; $\mathrm{dbSNP}$ = single nucleotide polymorphism database.

As the clinical suspect of PXE was not fully supported by results of molecular analysis, a skin biopsy was performed, and ultrastructural examination was conducted to assess the presence of calcified elastic fibers [19]. Ultrastructural analysis revealed scanty collagen bundles with fibrils of heterogeneous diameter and numerous dermal elastic fibers heavily calcified (Figure 1B) and deformed by mineral deposition.

\section{Discussion}

In PXE, ocular manifestations, which can be detected in many retinal diseases, represent the most challenging disability since vision impairment adversely affects daily functions and several aspects of patients' quality of life. Since next-generation sequencing is revolutionizing genetic testing and quickly replacing traditional methods in the diagnostic field, we adopted this approach focusing on 340 genes associated with the calcification process and/or being responsible for IRDs.

Analysis of calcification-related genes revealed only one rare sequence variant in $A B C C 6$. Diagnosed PXE patients with a monoallelic ABCC6 mutation have been already described [1], thus suggesting the involvement of other genes or the role of deep intronic variants. In our patient, a digenic inheritance as those described for $A B C C 6$ and GGCX [9] is unlikely, since all known calcification-related genes that were investigated did not show any rare sequence variant. Moreover, the occurrence of $A B C C 6$ pseudodominance can be excluded, since the patient's mother, being a carrier of the same rare sequence variant, did not exhibit any sign of PXE.

The patient was characterized by pattern dystrophy-like changes, and we know that these abnormalities are very frequent in PXE-related retinopathy, especially in the advanced stages of the disease [20]. However, since the patient was still young when he developed retinal changes and ophthalmological clinical pictures (pigment deposition at the fundus, subretinal fluid and RPE abnormalities at the OCT examination) might be compatible with the evolution of a vitelliform macular lesion (vitelliform macular dystrophy pattern dystrophy subtype), the possible contribution of the IMPG1 gene in the ocular phenotype of this patient represents an intriguing finding. IMPG1 variants, in fact, can cause both autosomal dominant and recessive forms of vitelliform macular dystrophies [21,22], and a patient heterozygous for the c. $1945 \mathrm{C}>\mathrm{T}$ variant has been reported to be diagnosed with dry age-related macular degeneration (DARMD) [18]. Therefore, the detection of this variant in our patient may indicate a copresence of both pathologic conditions (i.e., PXE and DARMD) or that IMPG1 interacts with $A B C C 6$ worsening the ophthalmologic PXE phenotype of the patient. 
Moreover, the patient described in this report was also a carrier of a pathogenic variant in the $A B C A 4$ gene [17]. This gene is a member of the $A B C$ transporter gene superfamily encoding an ATP-binding cassette transporter (retinal specific transmembrane $A B C A 4$ protein), which is localized to the rims of rods and cones [23]. The presence of an $A B C A 4$ pathogenic variant has been recently described in a patient affected by PXE, suggesting that mineralization of the Bruch's membrane and alterations of RPE and/or of photoreceptor function can synergically contribute to the pathological phenotype [13]. The rupture of calcified Bruch's membrane leads to choroidal neovascularization and in some cases to retinal dystrophy. However, the Bruch's membrane calcification is not pathognomonic of PXE, since it is also present for example in age-related macular degeneration. Gliem and collaborators [24] demonstrated that PXE ophthalmological alterations and age-related macular degeneration share phenotypic similarities consistent with common pathogenic pathways. Within this context, the $A B C A 4$ gene is of particular interest since it is responsible for a wide range of ocular manifestations (e.g., Stargardt disease, cone-rod dystrophy, retinitis pigmentosa, age-related macular degeneration, mild fundus flavimaculatus) [25-29], some of which have also been described in PXE patients [1]. Although $A B C A 4$-associated diseases are recessive, some patients with age-related macular degeneration or with a late-onset Stargardt's disease were described to be carriers of a single rare $A B C A 4$ variant $[30,31]$.

New rare sequence variants in $P O C 1 B$ and $R A X 2$ genes were found, but at present, their role in PXE remains speculative.

In the light of clinical examinations, biomolecular analyses and morphological evaluations, a diagnosis of PXE was made, and ophthalmologists were advised of the possible involvement of IRD genes in patient's ocular manifestations, in order to explain the severity of disease progression and to improve the knowledge on ophthalmological manifestations in rare diseases.

\section{Conclusions}

Although we cannot exclude the presence of rare sequence variants and/or functional polymorphisms in other genes not yet associated with PXE and/or IRDs, which may influence the disease progression, the present report provides important information to better understand the complexity of rare diseases, since even single cases are instrumental for researchers and physicians to improve their knowledge. In particular, this study highlights that, in PXE, rare sequence variants in IRD genes can be detected, thus widening the spectrum of IRD genes that may be involved in PXE and opening the door for investigating how IRD genes can act in synergy and/or in a complementary way with the $A B C C 6$ gene. Therefore, genetic screening using a wide-spectrum analysis approach can help ophthalmologists to better understand eye diseases and their manifestations, improving patient counseling. In addition, genetic testing on IRD genes in PXE patients could be important also for prognostic purposes (i.e., severity and progression of ophthalmological complications) and in terms of possible gene therapies, which are in progress for several IRD subtypes and are offering, for the first time, the prospect of delaying the time course of vision loss.

Author Contributions: Conceptualization, F.B. and D.Q.; formal analysis, F.D.L. and F.B.; investigation, F.D.L., D.P.M., V.M. and L.P.; data curation, F.D.L.; writing — original draft preparation, F.B. and D.Q.; writing - review and editing, F.B. and D.Q.; funding acquisition, D.Q. All authors have read and agreed to the published version of the manuscript.

Funding: This study was supported by PXE Italia Odv, grant number E96C18000600007 (DQ). L.P. is a recipient of a fellowship by PXE Italia Odv.

Institutional Review Board Statement: This study was done in accordance with the guidelines of the Declaration of Helsinki, and it was approved by Comitato Etico Area Vasta Centro regione Toscana (Project ID: 2018/13014).

Informed Consent Statement: Written informed consent has been obtained from the patient to publish this paper. 
Data Availability Statement: Authors declare that all related data are available in this manuscript.

Conflicts of Interest: The authors declare no conflict of interest.

\section{References}

1. Boraldi, F.; Murro, V.; Lofaro, F.D.; Mucciolo, D.P.; Costa, S.; Pavese, L.; Quaglino, D. Phenotypic Features and Genetic Findings in a Cohort of Italian Pseudoxanthoma Elasticum Patients and Update of the Ophthalmologic Evaluation Score. J. Clin. Med. 2021, 10, 2710. [CrossRef] [PubMed]

2. Marconi, B.; Bobyr, I.; Campanati, A.; Molinelli, E.; Consales, V.; Brisigotti, V.; Scarpelli, M.; Racchini, S.; Offidani, A. Pseudoxanthoma Elasticum and Skin: Clinical Manifestations, Histopathology, Pathomechanism, Perspectives of Treatment. Intractable Rare Dis. Res. 2015, 4, 113-122. [CrossRef]

3. Neidner, K.H. Cutaneous Manifestations. Clin. Dermatol. 1988, 6, 14-28. [CrossRef]

4. Murro, V.; Mucciolo, D.P.; Giorgio, D.; Pavese, L.; Boraldi, F.; Quaglino, D.; Finocchio, L.; Sodi, A.; Virgili, G.; Giansanti, F. Adaptive Optics Imaging in Patients Affected by Pseudoxanthoma Elasticum. Am. J. Ophthalmol. 2020, 224, 84-95. [CrossRef] [PubMed]

5. Lefthériotis, G.; Omarjee, L.; Le Saux, O.; Henrion, D.; Abraham, P.; Prunier, F.; Willoteaux, S.; Martin, L. The Vascular Phenotype in Pseudoxanthoma Elasticum and Related Disorders: Contribution of a Genetic Disease to the Understanding of Vascular Calcification. Front. Genet. 2013, 4, 4. [CrossRef]

6. Georgalas, I.; Tservakis, I.; Papaconstaninou, D.; Kardara, M.; Koutsandrea, C.; Ladas, I. Pseudoxanthoma Elasticum, Ocular Manifestations, Complications and Treatment. Clin. Exp. Optom. 2011, 94, 169-180. [CrossRef]

7. Quaglino, D.; Boraldi, F.; Lofaro, F.D. The Biology of Vascular Calcification. Int. Rev. Cell Mol. Biol. 2020, 354, 261-353. [CrossRef]

8. Le Saux, O.; Beck, K.; Sachsinger, C.; Silvestri, C.; Treiber, C.; Göring, H.H.; Johnson, E.W.; De Paepe, A.; Pope, F.M.; PasqualiRonchetti, I.; et al. A Spectrum of ABCC6 Mutations Is Responsible for Pseudoxanthoma Elasticum. Am. J. Hum. Genet. 2001, 69, 749-764. [CrossRef]

9. Li, Q.; Grange, D.K.; Armstrong, N.L.; Whelan, A.J.; Hurley, M.Y.; Rishavy, M.A.; Hallgren, K.W.; Berkner, K.L.; Schurgers, L.J.; Jiang, Q.; et al. Mutations in the GGCX and ABCC6 Genes in a Family with Pseudoxanthoma Elasticum-like Phenotypes. J. Investig. Dermatol. 2009, 129, 553-563. [CrossRef]

10. Nitschke, Y.; Baujat, G.; Botschen, U.; Wittkampf, T.; du Moulin, M.; Stella, J.; Le Merrer, M.; Guest, G.; Lambot, K.; TazarourtePinturier, M.-F.; et al. Generalized Arterial Calcification of Infancy and Pseudoxanthoma Elasticum Can Be Caused by Mutations in Either ENPP1 or ABCC6. Am. J. Hum. Genet. 2012, 90, 25-39. [CrossRef]

11. Boraldi, F.; Lofaro, F.D.; Costa, S.; Moscarelli, P.; Quaglino, D. Rare Co-Occurrence of Beta-Thalassemia and Pseudoxanthoma Elasticum: Novel Biomolecular Findings. Front. Med. 2020, 6, 322. [CrossRef]

12. Luo, H.; Faghankhani, M.; Cao, Y.; Uitto, J.; Li, Q. Molecular Genetics and Modifier Genes in Pseudoxanthoma Elasticum, a Heritable Multisystem Ectopic Mineralization Disorder. J. Investig. Dermatol. 2020, 141, 1148-1156. [CrossRef]

13. Mahroo, O.A.; Fujinami, K.; Moore, A.T.; Webster, A.R. Retinal Findings in a Patient with Mutations in ABCC6 and ABCA4. Eye 2018, 32, 1542-1543. [CrossRef] [PubMed]

14. Wang, K.; Statler, B.; Ramos, M.; DeBenedictis, M.J.; Babiuch, A.; Yuan, A.; Traboulsi, E.I. Hickam's Dictum: Pseudoxanthoma Elasticum and Usher Syndrome in a Single Patient. Ophthalmic Genet. 2020, 41, 465-469. [CrossRef] [PubMed]

15. Boraldi, F.; Lofaro, F.D.; Romano, O.; Grilli, A.; Losi, L.; Moscarelli, P.; Bicciato, S.; Quaglino, D. Exome Sequencing and Bioinformatic Approaches Reveals Rare Sequence Variants Involved in Cell Signalling and Elastic Fibre Homeostasis: New Evidence in the Development of Ectopic Calcification. Cell Signal. 2019, 59, 131-140. [CrossRef]

16. Kopanos, C.; Tsiolkas, V.; Kouris, A.; Chapple, C.E.; Albarca Aguilera, M.; Meyer, R.; Massouras, A. VarSome: The Human Genomic Variant Search Engine. Bioinformatics 2019, 35, 1978-1980. [CrossRef] [PubMed]

17. Schulz, H.L.; Grassmann, F.; Kellner, U.; Spital, G.; Rüther, K.; Jägle, H.; Hufendiek, K.; Rating, P.; Huchzermeyer, C.; Baier, M.J.; et al. Mutation Spectrum of the ABCA4 Gene in 335 Stargardt Disease Patients From a Multicenter German Cohort-Impact of Selected Deep Intronic Variants and Common SNPs. Investig. Ophthalmol. Vis. Sci. 2017, 58, 394-403. [CrossRef]

18. Kersten, E.; Geerlings, M.J.; Pauper, M.; Corominas, J.; Bakker, B.; Altay, L.; Fauser, S.; de Jong, E.K.; Hoyng, C.B.; den Hollander, A.I. Genetic Screening for Macular Dystrophies in Patients Clinically Diagnosed with Dry Age-related Macular Degeneration. Clin. Genet. 2018, 94, 569-574. [CrossRef]

19. Boraldi, F.; Lofaro, F.D.; Losi, L.; Quaglino, D. Dermal Alterations in Clinically Unaffected Skin of Pseudoxanthoma Elasticum Patients. J. Clin. Med. 2021, 10, 500. [CrossRef]

20. Murro, V.; Mucciolo, D.P.; Giorgio, D.; Sodi, A.; Boraldi, F.; Quaglino, D.; Virgili, G.; Giansanti, F. Pattern Dystrophy-like Changes and Coquille d'oeuf Atrophy in Elderly Patients Affected by Pseudoxanthoma Elasticum. Graefes Arch. Clin. Exp. Ophthalmol. 2020, 258, 1881-1892. [CrossRef]

21. Manes, G.; Meunier, I.; Avila-Fernández, A.; Banfi, S.; Le Meur, G.; Zanlonghi, X.; Corton, M.; Simonelli, F.; Brabet, P.; Labesse, G.; et al. Mutations in IMPG1 Cause Vitelliform Macular Dystrophies. Am. J. Hum. Genet. 2013, 93, 571-578. [CrossRef] [PubMed]

22. Diakatou, M.; Manes, G.; Bocquet, B.; Meunier, I.; Kalatzis, V. Genome Editing as a Treatment for the Most Prevalent Causative Genes of Autosomal Dominant Retinitis Pigmentosa. Int. J. Mol. Sci. 2019, 20, 2542. [CrossRef] [PubMed]

23. Tsybovsky, Y.; Molday, R.S.; Palczewski, K. The ATP-Binding Cassette Transporter ABCA4: Structural and Functional Properties and Role in Retinal Disease. Adv. Exp. Med. Biol. 2010, 703, 105-125. [CrossRef] [PubMed] 
24. Gliem, M.; Müller, P.L.; Birtel, J.; McGuinness, M.B.; Finger, R.P.; Herrmann, P.; Hendig, D.; Holz, F.G.; Charbel Issa, P. Quantitative Fundus Autofluorescence in Pseudoxanthoma Elasticum. Investig. Ophthalmol. Vis. Sci. 2017, 58, 6159-6165. [CrossRef] [PubMed]

25. Cremers, F.P.; van de Pol, D.J.; van Driel, M.; den Hollander, A.I.; van Haren, F.J.; Knoers, N.V.; Tijmes, N.; Bergen, A.A.; Rohrschneider, K.; Blankenagel, A.; et al. Autosomal Recessive Retinitis Pigmentosa and Cone-Rod Dystrophy Caused by Splice Site Mutations in the Stargardt's Disease Gene ABCR. Hum. Mol. Genet. 1998, 7, 355-362. [CrossRef] [PubMed]

26. Martínez-Mir, A.; Paloma, E.; Allikmets, R.; Ayuso, C.; del Rio, T.; Dean, M.; Vilageliu, L.; Gonzàlez-Duarte, R.; Balcells, S. Retinitis Pigmentosa Caused by a Homozygous Mutation in the Stargardt Disease Gene ABCR. Nat. Genet. 1998, 18, 11-12. [CrossRef] [PubMed]

27. Allikmets, R.; Shroyer, N.F.; Singh, N.; Seddon, J.M.; Lewis, R.A.; Bernstein, P.S.; Peiffer, A.; Zabriskie, N.A.; Li, Y.; Hutchinson, A.; et al. Mutation of the Stargardt Disease Gene (ABCR) in Age-Related Macular Degeneration. Science 1997, 277, $1805-1807$. [CrossRef]

28. Allikmets, R.; Singh, N.; Sun, H.; Shroyer, N.F.; Hutchinson, A.; Chidambaram, A.; Gerrard, B.; Baird, L.; Stauffer, D.; Peiffer, A.; et al. A Photoreceptor Cell-Specific ATP-Binding Transporter Gene (ABCR) Is Mutated in Recessive Stargardt Macular Dystrophy. Nat. Genet. 1997, 15, 236-246. [CrossRef]

29. Zernant, J.; Schubert, C.; Im, K.M.; Burke, T.; Brown, C.M.; Fishman, G.A.; Tsang, S.H.; Gouras, P.; Dean, M.; Allikmets, R. Analysis of the ABCA4 Gene by Next-Generation Sequencing. Investig. Ophthalmol. Vis. Sci. 2011, 52, 8479-8487. [CrossRef]

30. Fritsche, L.G.; Fleckenstein, M.; Fiebig, B.S.; Schmitz-Valckenberg, S.; Bindewald-Wittich, A.; Keilhauer, C.N.; Renner, A.B.; Mackensen, F.; Mößner, A.; Pauleikhoff, D.; et al. A Subgroup of Age-Related Macular Degeneration Is Associated with Mono-Allelic Sequence Variants in the ABCA4 Gene. Investig. Ophthalmol. Vis. Sci. 2012, 53, 2112-2118. [CrossRef]

31. Westeneng-van Haaften, S.C.; Boon, C.J.F.; Cremers, F.P.M.; Hoefsloot, L.H.; den Hollander, A.I.; Hoyng, C.B. Clinical and Genetic Characteristics of Late-Onset Stargardt's Disease. Ophthalmology 2012, 119, 1199-1210. [CrossRef] [PubMed] 